\title{
Chelativorans multitrophicus gen. nov., sp. nov. and Chelativorans oligotrophicus sp. nov., aerobic EDTA-degrading bacteria
}

Correspondence

Yuri A. Trotsenko

trotsenko@ibpm.pushchino.ru

\author{
Nina V. Doronina, ${ }^{1}$ Elena N. Kaparullina, ${ }^{1}$ Yuri A. Trotsenko, ${ }^{1}$ \\ Bernd Nörtemann, ${ }^{2}$ Margarete Bucheli-Witschel, ${ }^{3}$ Hans-Ueli Weilenmann ${ }^{3}$ \\ and Thomas Egli ${ }^{3}$
${ }^{1}$ G. K. Skryabin Institute of Biochemistry and Physiology of Microorganisms, Russian Academy of Sciences and Pushchino State University, Pushchino, Moscow region, 142290, Russia and Technology), 8600 Dubendorf, Switzerland \\ ${ }^{2}$ Institute of Biochemical Engineering, Technische Universität Braunschweig, 38106, Germany \\ ${ }^{3}$ Department of Environmental Microbiology, EAWAG (Swiss Federal Institute of Aquatic Science
}

\begin{abstract}
Two previously isolated strains (DSM $9103^{\top}$ and LPM-4 ${ }^{\top}$ ) able to grow with EDTA (facultatively and obligately, respectively) as the source of carbon, nitrogen and energy were investigated in order to clarify their taxonomic positions. The strains were strictly aerobic, Gram-negative, asporogenous and non-motile rods that required biotin for growth. Reproduction occurred by binary fission. The strains were mesophilic and neutrophilic. Their major fatty acids were summed feature 7 (consisting of $\mathrm{C}_{18: 1} \omega 7 c, \mathrm{C}_{18: 1} \omega 9 t$ and/or $\mathrm{C}_{18: 1} \omega 12 t$ ) and $\mathrm{C}_{19: 0}$ cyclo $\omega 8 \mathrm{c}$. The polyamine pattern revealed homospermidine as a major polyamine. Predominant polar lipids were phosphatidylcholine, phosphatidylglycerol, phosphatidylethanolamine, phosphatidyldimethylethanolamine, phosphatidylmonomethylethanolamine and diphosphatidylglycerol.

Mesorhizobium-specific ornithine lipid was absent. The predominant isoprenoid quinone was Q10. The DNA G+C values were 60.8 and $63.1 \mathrm{~mol} \%\left(T_{\mathrm{m}}\right)$ for strains $L P M-4^{\top}$ and DSM $9103^{\top}$, respectively. The level of $16 \mathrm{~S}$ rRNA gene sequence similarity between these EDTA-utilizers was 99.3\% while the DNA-DNA hybridization value was only $37 \%$. Both strains were phylogenetically related to members of the genera Aminobacter and Mesorhizobium (95-97\% sequence similarity). However, DNA-DNA hybridization values between the novel EDTAdegrading strains and Aminobacter aminovorans DSM $7048^{\top}$ and Mesorhizobium loti DSM $2626^{\top}$ were low (10-11\%). Based on their genomic and phenotypic properties, the new alphaproteobacterial strains are assigned to a novel genus, Chelativorans gen. nov., with the names Chelativorans multitrophicus sp. nov. (type strain DSM $9103^{\top}=\mathrm{VKM} \mathrm{B}-2394^{\top}$ ) and Chelativorans oligotrophicus sp. nov. (type strain LPM- $4^{\top}=$ VKM B-2395 ${ }^{\top}=$ DSM $19276^{\top}$ ).
\end{abstract}

EDTA is a chelating agent from the group of aminopolycarboxylic acids that are able to form stable, water-soluble

Abbreviations: APL, aminophospholipid; DPG, diphosphatidylglycerol; PC, phosphatidylcholine; PDE, phosphatidyldimethylethanolamine; $\mathrm{PE}$, phosphatidylethanolamine; $\mathrm{PG}$, phosphatidylglycerol; $\mathrm{PHB}$, poly- $\beta$ hydroxybutyrate; PL, phospholipids; PME, phosphatidylmonomethylethanolamine.

The GenBank/EMBL/DDBJ accession numbers for the $16 \mathrm{~S}$ rRNA gene sequences of strains DSM $9103^{\top}$ and $L P M-4^{\top}$ are EF457243 and EF457242, respectively.

The TLC for the polar lipid analysis and four additional phylogenetic trees are available with the online version of this paper. A comparison of the major fatty acid contents of the novel strains and those of related genera is presented as a supplementary table. complexes with many metal ions. At present, the amount of EDTA utilized worldwide amounts to some 103000 tonnes per year. It is used in many diverse fields including the photographic and galvanic industries, in textile and paper manufacturing, for decontamination of nuclear power installations, as a component of industrial cleaners, as an additive in cosmetics and food products, in gas scrubbing for the removal of hydrogen sulfide from waste gases and in agricultural applications to improve the uptake of micronutrients to correct trace metal deficiencies in plants (Potthoff-Karl et al., 1996; Weilenmann et al., 2004). The predominantly water-based use of EDTA and the recalcitrance of EDTA to biodegradation have resulted in high concentrations of this agent in surface waters. The extensive environmental EDTA pollution that has been observed in 
recent years has become a cause for concern, in particular because of its possible contribution to the mobilization of heavy and toxic metal ions deposited in sediments and soils and also due to the contamination of drinking water (Sillanpaa, 1997; Bucheli-Witschel \& Egli, 2001). In order to develop appropriate biotechnological processes to deal with EDTA pollution, the isolation and detailed characterization of micro-organisms able to mineralize EDTA is required.

So far, only a few EDTA-degrading alphaproteobacterial strains have been isolated as pure cultures, i.e. Agrobacterium radiobacter sp. ATCC 55002 (Lauff et al., 1990; Palumbo et al., 1994), subsequently reclassified as Rhizobium radiobacter (Young et al., 2001), and the Gram-negative strains BNC1 (=DSM 6780; Nörtemann, 1992), DSM 9103 (Weilenmann et al., 2004), LPM-4 ${ }^{\mathrm{T}}$ (Chistyakova et al., 2005) and ANP11 (Nörtemann, 2005). The four latter strains have several features in common, for example growth with EDTA and no growth with iron-complexed EDTA. The present study focused on the taxonomic description and identification of strains DSM $9103^{\mathrm{T}}$ and LPM- $4^{\mathrm{T}}$.

Strains DSM $9103^{\mathrm{T}}$ and $\mathrm{LPM}-4^{\mathrm{T}}$ were grown on a mineral medium, 'E', containing $\left(\mathrm{l}^{-1}\right)$ : $1.0 \mathrm{~g} \mathrm{Na}_{4}$ EDTA; $1.0 \mathrm{~g}$ $\mathrm{MgSO}_{4} .7 \mathrm{H}_{2} \mathrm{O} ; 0.26 \mathrm{~g} \mathrm{KH}_{2} \mathrm{PO}_{4} ; 0.4 \mathrm{~g} \mathrm{CaCl}_{2} .2 \mathrm{H}_{2} \mathrm{O}$ and $4 \mathrm{~g}$ $\mathrm{NaHPO}_{4} \cdot 12 \mathrm{H}_{2} \mathrm{O}$ at $\mathrm{pH}$ 7.0. Medium E was supplemented with $2 \mathrm{ml}$ Widdel's trace element solution (Pfennig et al., 1981) and $1 \mathrm{ml}$ vitamin solution (Egli et al., 1988) per litre.

Physiological tests were performed according to Gerhardt et al. (1994). Utilization of a wide range of growth substrates was determined after the strains had been cultivated on mineral medium E for 2 weeks with EDTA replaced by $1 \%\left(\mathrm{NH}_{4}\right)_{2} \mathrm{SO}_{4}$ and various carbon compounds (more than 60 were tested). The ability of the strains to undergo autotrophic growth on $\mathrm{H}_{2}+\mathrm{CO}_{2}+\mathrm{O}_{2}$ or under $\mathrm{CH}_{4}+\mathrm{O}_{2}$ was tested as previously described by Doronina et al. (2000). Carbohydrates, organic acids and amino acids were added at concentrations of $0.05-0.3 \%$ $(\mathrm{w} / \mathrm{v})$, while alcohols were added at concentrations of $0.2-$ $0.5 \%(\mathrm{v} / \mathrm{v})$. The novel bacterial strains were stored in liquid mineral medium $\mathrm{E}$ for 1 month, on agar slants at $4{ }^{\circ} \mathrm{C}$ for 2 weeks or in a freeze-dried state with a protectant (skimmed milk) for over a year.
Cell morphology was examined using batch cultures grown for $24 \mathrm{~h}$ on medium $\mathrm{E}$ for both strains and on medium supplemented with fumarate and ammonium chloride $\left(0.5 \mathrm{~g} \mathrm{l}^{-1}\right)$ for strain DSM $9103^{\mathrm{T}}$. An aliquot of cell suspension was mounted on a Formvar-coated copper grid and stained with $0.2 \%(\mathrm{w} / \mathrm{v})$ phosphotungstic acid ( $\mathrm{pH}$ 7.2). For thin sectioning, cells were collected by centrifugation and pre-fixed with $1.5 \%(\mathrm{v} / \mathrm{v})$ glutaraldehyde in $0.05 \mathrm{M}$ cacodylate buffer ( $\mathrm{pH} 7.2)$ and washed three times with $1 \%(\mathrm{w} / \mathrm{v})$ $\mathrm{OsO}_{4}$ in $0.05 \mathrm{M}$ cacodylate buffer (pH 7.2) for $3 \mathrm{~h}$ at $20{ }^{\circ} \mathrm{C}$. After dehydration in a series of alcohols, cells were embedded in Spurr epoxy resin and sectioned with a microtome (2128 Ultratome; LKB). Ultrathin sections were mounted on copper grids and double-stained with uranyl acetate and lead citrate (Fig. 1). Negatively stained preparations and thin sections were viewed with a transmission electron microscope (JEM$100 \mathrm{~B}$; JEOL) at operating voltages of $60 \mathrm{kV}$ and $80 \mathrm{kV}$, respectively. Cells of the novel isolates were Gram-negative, non-motile, asporogenous rods that were 0.5-1.0 $\times 0.7-$ $2.0 \mu \mathrm{m}$ in size. Cells of both strains multiplied by binary fission. When grown on medium $\mathrm{E}$ agar, colonies of both strains were white and $0.1-0.3 \mathrm{~mm}$ in diameter after 7 days incubation at $30{ }^{\circ} \mathrm{C}$. The metabolic features of the EDTAdegrading strains have been described previously (Witschel et al., 1997; Doronina et al., 2006).

Sensitivity to antibiotics was examined by placing Difco discs on cells spread on agar plates. The discs contained the following antibiotics $(\mu \mathrm{g})$ : gentamicin $(10)$, neomycin $(30)$, streptomycin (10), ampicillin (10), nalidixic acid (30), lincomycin (2), oxacillin (10), neomycin (30) and novobiocin (5). The effect of antibiotics on cell growth was assessed after 2 weeks.

The poly- $\beta$-hydroxybutyrate (PHB) content in the cell biomass was determined by reverse-phase HPLC (Korotkova et al., 1997).

Fatty acids were extracted from cells in the exponential growth phase [medium E containing $1 \mathrm{~g} \mathrm{l}^{-1}$ EDTA and trypticase soy broth supplemented with $1.5 \%$ (w/v) agar]. A $200 \mu \mathrm{l}$ aliquot of a $5.4 \mathrm{M}$ solution of anhydrous $\mathrm{HCl}$ in methanol was added to $30 \mathrm{mg}$ dry biomass and the mixture was heated at $70{ }^{\circ} \mathrm{C}$ for $2 \mathrm{~h}$. The methyl esters of fatty acids and aldehyde derivatives

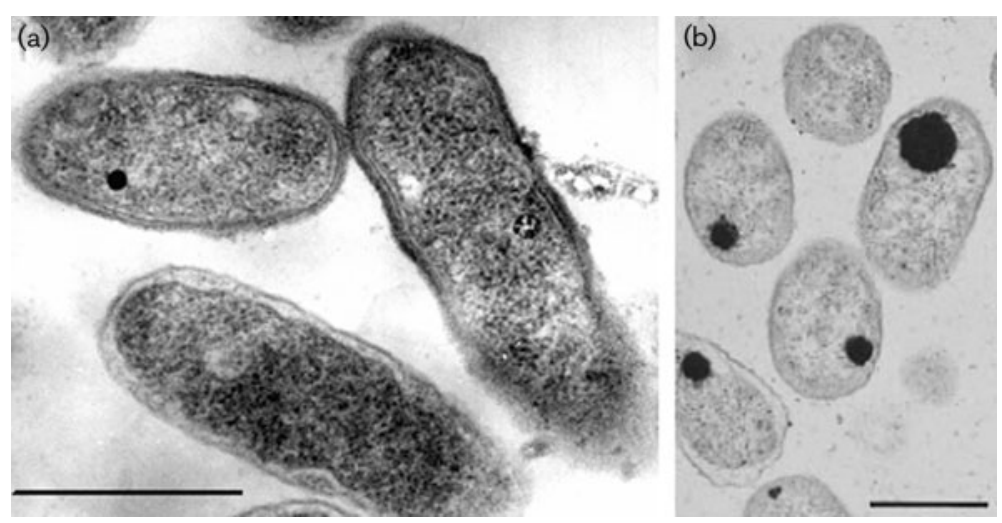

Fig. 1. Electron micrographs of ultrathin sections of EDTA-grown cells of strain LPM- $4^{\top}$ (a) and strain DSM $9103^{\top}$ (b) showing electrondense polyphosphate inclusions. Bars, $0.5 \mu \mathrm{m}$. 
obtained were extracted twice with $100 \mu \mathrm{l}$ hexane. The extract was dried and silylated in $20 \mu \mathrm{l}, \mathrm{O}$-bis(trimethylsilyl)trifluoroacetamide for $15 \mathrm{~min}$ at $65^{\circ} \mathrm{C}$. A $1 \mu \mathrm{l}$ sample of the reaction mixture was analysed with a GC-MS system (model HP-5985B; Hewlett Packard) equipped with a capillary column $(25 \times 0.25 \mathrm{~mm})$ consisting of fused quartz containing an Ultra-1 non-polar methylsilicone phase. The temperature program was run from $150{ }^{\circ} \mathrm{C}(2 \mathrm{~min}$ isotherm $)$ to $250{ }^{\circ} \mathrm{C}$ at $5{ }^{\circ} \mathrm{C} \mathrm{min}{ }^{-1}$ and then from 250 to $300{ }^{\circ} \mathrm{C}$ at $10{ }^{\circ} \mathrm{C} \mathrm{min}{ }^{-1}$. Data processing was carried out with a computer (HP-1000; Hewlett Packard) by using the standard programs of the GCMS system (Hewlett Packard) as described by Doronina et al. (2003). The fatty acid profile of strain DSM $9103^{\mathrm{T}}$ was composed of summed feature $7\left(\mathrm{C}_{18: 1} 7 c, \mathrm{C}_{18: 1} 9 t\right.$ and/or $\left.\mathrm{C}_{18: 1} 12 t, 67.63 \%\right)$ and $\mathrm{C}_{19: 0}$ cyclo $\omega 8 c(23.05 \%)$. Strain LPM $-4^{\mathrm{T}}$ had rather similar profile containing summed feature $7(67.31 \%)$ and $\mathrm{C}_{19: 0}$ cyclo $\omega 8 c(20.72 \%)$ (see Supplementary Table S1 in IJSEM Online). Species of the genera Aminobacter, Pseudaminobacter and Mesorhizobium also contain summed feature 7 , summed feature $4\left(\mathrm{C}_{16: 1} 7 c\right.$ and/ or $\mathrm{C}_{15: 0}$ iso 2-OH) and $\mathrm{C}_{16: 0}, \mathrm{C}_{17: 0}$ iso and $\mathrm{C}_{18: 0}$ fatty acids. The hydroxy fatty acid $\mathrm{C}_{12: 0} 3-\mathrm{OH}$ is also present in species of the genus Aminobacter. Fatty acids $\mathrm{C}_{17: 1} \omega 8 c$ and $\mathrm{C}_{20: 1} \omega 9 t$ were not detected in strains DSM $9103^{\mathrm{T}}$ and LPM- $4^{\mathrm{T}}$. The absence of fatty acids $\mathrm{C}_{15: 0}$ iso $3-\mathrm{OH}, \mathrm{C}_{17: 1} \omega 8 \mathrm{c}$ and $\mathrm{C}_{20: 1} \omega 9 t$ distinguished the novel strains from species of the genus Pseudaminobacter. In contrast to the novel strains, species of the genus Mesorhizobium contained high amounts of fatty acids $\mathrm{C}_{16: 0}$ and $\mathrm{C}_{18: 0}$ and low levels of summed feature 7 . The absence of 11 methyl $\mathrm{C}_{18: 1} \omega 7 c$ and $\mathrm{C}_{17: 0}$ cyclo fatty acids distinguished novel strains DSM $9103^{\mathrm{T}}$ and LPM $-4^{\mathrm{T}}$ from the members of the genus Mesorhizobium.

For analysis of the cellular phospholipids, the novel strains were grown in minimal medium E containing $1 \mathrm{~g} \mathrm{l}^{-1}$ EDTA in batch culture at $28{ }^{\circ} \mathrm{C}$. Cells of strains LPM-4 ${ }^{\mathrm{T}}$ and DSM $9103^{\mathrm{T}}$ in the exponential growth phase (4 days) were harvested by centrifugation at $5000 \mathrm{~g}$ for $20 \mathrm{~min}$. Cellular phospholipids were extracted using chloroform: methanol $(1: 2, \mathrm{v} / \mathrm{v})$. The suspension was stirred for $1 \mathrm{~h}$ in an ice bath and was then centrifuged $(5000 \mathrm{~g}, 20 \mathrm{~min})$ to separate the two phases. The extraction procedure was performed twice and the upper phases were combined. Chloroform $(2 \mathrm{ml})$ and distilled water $(2 \mathrm{ml})$ were added to the supernatant with careful shaking for $15 \mathrm{~min}$ in an ice bath. The mixture was then centrifuged and three phases were separated. The lower phase containing the polar lipids was evaporated at $30{ }^{\circ} \mathrm{C}$ and dissolved in $200 \mu \mathrm{l}$ chloroform. Polar lipids were separated by two-dimensional TLC (Kieselgel 60, $10 \times 10 \mathrm{~cm}$, Merck) using the solvent systems chloroform:methanol: water $(65: 25: 4)$ for the first dimension, followed by chloroform: methanol:acetic acid:water $(85: 12: 15: 4)$ for the second dimension. Polar lipids were analysed as described by Tindall (1990). Non-specific detection of total lipids on the twodimensional TLC plates was performed with iodine vapours. To detect lipids carrying free amino groups, the plates were sprayed with $0.2 \%(\mathrm{w} / \mathrm{v})$ ninhydrin dissolved in acetone followed by heating of the plates at $120{ }^{\circ} \mathrm{C}$. To detect phospholipids, two reagents were used: (i) $5 \mathrm{ml} 60 \% \mathrm{w} / \mathrm{v}$ perchloric acid, $10 \mathrm{ml} 1 \mathrm{M} \mathrm{HCl}$ and $25 \mathrm{ml} 4 \%$ (w/v) ammonium molybdate (Skidmore \& Entenmann, 1962); (ii) $10 \% \mathrm{CuSO}_{4}$ in $8 \% \mathrm{H}_{3} \mathrm{PO}_{4}$ (Andreev \& Galchenko, 1983) as seen in Supplementary Fig. S1 (available at IJSEM Online).

The polar lipids of strains DSM $9103^{\mathrm{T}}$ and LPM- $4^{\mathrm{T}}$ were phosphatidylcholine (PC), phosphatidylglycerol (PG), phosphatidylethanolamine (PE), phosphatidyldimethylethanolamine (PDE), phosphatidylmonomethylethanolamine (PME) and diphosphatidylglycerol (DPG) (see Supplementary Fig. S1). This polar lipid profile was similar to those reported for species of the related genera Aminobacter, Pseudaminobacter and Mesorhizobium. The presence of the unknown phospholipids (PL1-PL3) and the unidentified aminophospholipid (APL) distinguished strains DSM $9103^{\mathrm{T}}$ and LPM-4 $4^{\mathrm{T}}$ from members of the genera Aminobacter and Pseudaminobacter. Strains DSM $9103^{\mathrm{T}}$ and LPM-4 ${ }^{\mathrm{T}}$ did not contain the Mesorhizobiumspecific ornithine lipid, which was not reported to contain a phosphate group (Choma \& Komaniecka, 2002).

Polyamines of strains LPM-4 ${ }^{\mathrm{T}}$ and DSM $9103^{\mathrm{T}}$ were extracted according to the methods of Tkachenko et al. (2006). The dansylated polyamines were separated by using HPLC (Waters) equipped with two model 510 HPLC pumps, a U6K injector and a reversed-phase column (Hypersil ODS RP $18,250 \times 4.6 \mathrm{~mm}, 5 \mu \mathrm{m}$ particles) as described by Altenburger et al. (1996). The polyamine patterns for strains DSM $9103^{\mathrm{T}}$ and LPM-4 $4^{\mathrm{T}}$ were similar and consisted of large amounts of triamine sym-homospermidine $[30.2 \mu \mathrm{mol}$ (g dry $\left.\mathrm{wt})^{-1}\right]$, putrescine $\left[6.5 \mu \mathrm{mol}(\mathrm{g} \text { dry wt})^{-1}\right]$ and spermidine $\left[5.3 \mu \mathrm{mol}\right.$ (g dry wt) $\left.{ }^{-1}\right]$. The genera Aminobacter and Mesorhizobium are characterized by the presence of symhomospermidine as the predominant compound, high amounts of putrescine and low amounts of spermidine. The major polyamines of the genus Pseudaminobacter are spermidine $\left[32.2 \mu \mathrm{mol}(\mathrm{g} \text { dry } \mathrm{wt})^{-1}\right]$, sym-homospermidine $\left[18.6 \mu \mathrm{mol}\left(\mathrm{g} \mathrm{dry} \mathrm{wt}^{-1}\right]\right.$ and putrescine $[15.6 \mu \mathrm{mol}$ (g dry $\mathrm{wt})^{-1}$ ] (the level of polyamines given for the type species Pseudaminobacter salicylatoxidans $\mathrm{BN} 12^{\mathrm{T}}$; Kämpfer et al., 1999). Strains DSM $9103^{\mathrm{T}}$ and $\mathrm{LPM}-4^{\mathrm{T}}$ could be distinguished from members of the genus Pseudaminobacter by the minor amounts of putrescine and spermidine.

Ubiquinones were extracted and purified according to Collins (1985). Analysis was performed by MS (MX-1310; Finnigan). The quinone system of strains DSM $9103^{\mathrm{T}}$ and LPM $-4^{\mathrm{T}}$ comprised major amounts of Q-10 $(98 \%)$ and minor amounts of Q-9. This pattern was in agreement with the ubiquinone pattern reported for the type species of the genera Aminobacter (Urakami et al., 1992), Pseudaminobacter (Kämpfer et al., 1999) and Mesorhizobium (Jarvis et al., 1982, 1997).

DNA was isolated and purified according to Marmur (1961). DNA-DNA relatedness was determined as described previously (Doronina et al., 2000). DNA-DNA relatedness between strains DSM $9103^{\mathrm{T}}$ and $\mathrm{LPM}-4^{\mathrm{T}}$ was $37 \%$. The DNA-DNA relatedness value between strains LPM- $4^{\mathrm{T}}$ and 
$\mathrm{BNC1}$ was $51 \%$, indicating that the strains belong to separate species.

Other EDTA-degrading strains appear to be very closely related or even identical to strain DSM $9103^{\mathrm{T}}$ (Nörtemann, 1999, 2005; Nörtemann et al., 2004). In particular, strain BNC1, described formerly as Mesorhizobium sp. BNC1 and for which the genome has already been sequenced by the Joint Genome Institute (see http://cmr.jcvi.org/tigr-scripts/ CMR/GenomePage.cgi?org=ntms05), exhibited $100 \%$ relatedness in DNA-DNA hybridizations with strain DSM $9103^{\mathrm{T}}$. This result means that the possibility that these organisms are identical cannot be excluded. A more detailed comparative study of strains DSM $9103^{\mathrm{T}}$, BNC1 and ANP11 is in progress.

The DNA-DNA relatedness values of strains DSM $9103^{\mathrm{T}}$ and LPM-4 ${ }^{\mathrm{T}}$ with Aminobacter aminovorans DSM $7048^{\mathrm{T}}$ and Mesorhizobium loti DSM $2626^{\mathrm{T}}$ were low (10-11\%). Hence, the results of the DNA-DNA hybridizations demonstrated that strains DSM $9103^{\mathrm{T}}, \mathrm{BNC} 1$ and $\mathrm{LPM}-4^{\mathrm{T}}$ were clearly separated from representatives of the genera Aminobacter and Mesorhizobium.

DNA $\mathrm{G}+\mathrm{C}$ content was determined by using the thermal denaturation $\left(T_{\mathrm{m}}\right)$ method with a spectrophotometer (DU-8B; Beckman) at a heating rate of $0.5{ }^{\circ} \mathrm{C} \min ^{-1}$. The calculation was performed according to Owen \& Lapage (1976) using the equation: $\mathrm{mol} \mathrm{G}+\mathrm{C}=\left(T_{\mathrm{m}} \cdot 2.08\right)-106.4$. The DNA of Escherichia coli K-12 was used as a standard. The DNA G + C contents of strains LPM- $4^{\mathrm{T}}$ and DSM $9103^{\mathrm{T}}$ were found to be 60.8 and $63.1 \mathrm{~mol} \%\left(T_{\mathrm{m}}\right)$, respectively.

The 16S rRNA genes of the novel strains were amplified and sequenced (Lane, 1991). The $16 \mathrm{~S}$ rRNA gene sequences were aligned against those of representative taxa of the phylum Proteobacteria obtained from the GenBank database by using CLUSTAL w software (http://www.genebee. msu.su/clustal). Evolutionary distances were calculated by pairwise comparison of the aligned sequences (Jukes \& Cantor, 1969), excluding all positions where there was a gap in any sequence in the alignment. In total, 1360 nucleotides for strains LPM- ${ }^{\mathrm{T}}$ and DSM $9103^{\mathrm{T}}$ were used in the analysis. Phylogenetic relationships were determined by the neighbour-joining method and the programs from the TREECON software package (version 1.3b; Van de Peer \& De Wachter, 1994), the PHYLIP package (v. 3.63), using the SEQBOOT, DNAML programs with bootstrap analysis of 100 trees, and MEGA version 4.0 (Tamura et al., 2007). The phylogenetic trees were constructed by using various functions implemented in the TREECON program package (Fig. 2) and TreeView (Win32) version 1.6.6. (http:// taxonomy.zoology.gla.ac.uk/rod/rod.html) (see Supplementary Fig. S2 in IJSEM Online) and MEGA4 (see Supplementary Figs S3-S5).

According to $16 \mathrm{~S}$ rRNA gene sequence analysis, strains DSM $9103^{\mathrm{T}}$ and LPM-4 $4^{\mathrm{T}}$ showed $99.3 \%$ similarity. They were closely related to members of the genera Aminobacter (94.8-95.9\%), Mesorhizobium (94.2-96.9\%) and Pseuda- minobacter (95.0-95.7\%) (Fig. 2 and Supplementary Fig. S2). The genera Aminobacter and Mesorhizobium had the highest sequence similarity $(94.6-98.2 \%)$ followed by Aminobacter and Pseudaminobacter (96.4-97.0\%) and Mesorhizobium and Pseudaminobacter (93.1-97.2\%). The 16S rRNA gene sequence of strain DSM $9103^{\mathrm{T}}$ was most similar $(99.9 \%$ similarity) to that of strain BNC1 (Fig. 2 and Supplementary Fig. S2). Both of these strains could be included as members of the same species as suggested previously on the basis of the morphological, cytophysiological and biochemical data for strain BNC1 (Nörtemann, 1992; Bohuslavek et al., 2001). In the phylogenetic trees (see Fig. 2 and Supplementary Figs S2-S4), the novel EDTA-degrading bacteria represented a separate branch within the class Alphaproteobacteria.

Based on phenotypic and genotypic characteristics, strains DSM $9103^{\mathrm{T}}$ and LPM-4 $4^{\mathrm{T}}$ should be placed in a separate new genus for which the name Chelativorans gen. nov. is proposed. Strains DSM $9103^{\mathrm{T}}$ and LPM-4 ${ }^{\mathrm{T}}$ represent novel species within this genus for which the names Chelativorans multitrophicus gen. nov., sp. nov. and Chelativorans oligotrophicus sp. nov. are proposed, respectively. The key properties that differentiate the new genus from related genera of the class Alphaproteobacteria are listed in Table 1. Members of the genus Chelativorans gen. nov. can be distinguished from the genus Aminobacter by their inability to grow on methylated amines due to the absence of the appropriate $\mathrm{C}_{1}$ enzymes, by the phospholipid and fatty acid profiles, by reproduction by binary fission, by the requirement for biotin and by the absence of PHB granules. Members of the genus Chelativorans gen. nov. can be distinguished from those of the genus Mesorhizobium by physiological differences, by some differences in the cellular fatty acids, by the absence of PHB granules and the presence of aminophospholipid (APL) in the polar lipid profile. Members of the genus Mesorhizobium are able to invade the root hairs of a wide range of plants and instigate the production of root nodules where atmospheric nitrogen can be reduced. However, a PCR amplification test using primers specific for the nifH gene (Fedorov et al. 2008) was negative in the novel strains, suggesting that they were not diazotrophs. In addition, representatives of the genera Mesorhizobium and Aminobacter are commonly pleomorphic and motile. Due to poor phenotypic descriptions for the genera Aquamicrobium and Defluvibacter, it is difficult to compare them with members of the genus Chelativorans gen. nov. However, these taxa are clearly distant phylogenetically (94.6-95.2\% gene sequence similarity). Organisms that share 16S rRNA gene sequence similarities of lower than $95 \%$ are usually regarded as belonging to separate bacterial genera (Stackebrandt \& Goebel, 1994). Formal descriptions of the new genus and the two novel species are given below.

\section{Description of Chelativorans gen. nov.}

Chelativorans (Che.la'ti.vor.ans. N.L. n. chelatum a chelate; L. part. adj. vorans devouring; N.L. masc. n. Chelativorans a bacterium digesting metal chelates). 


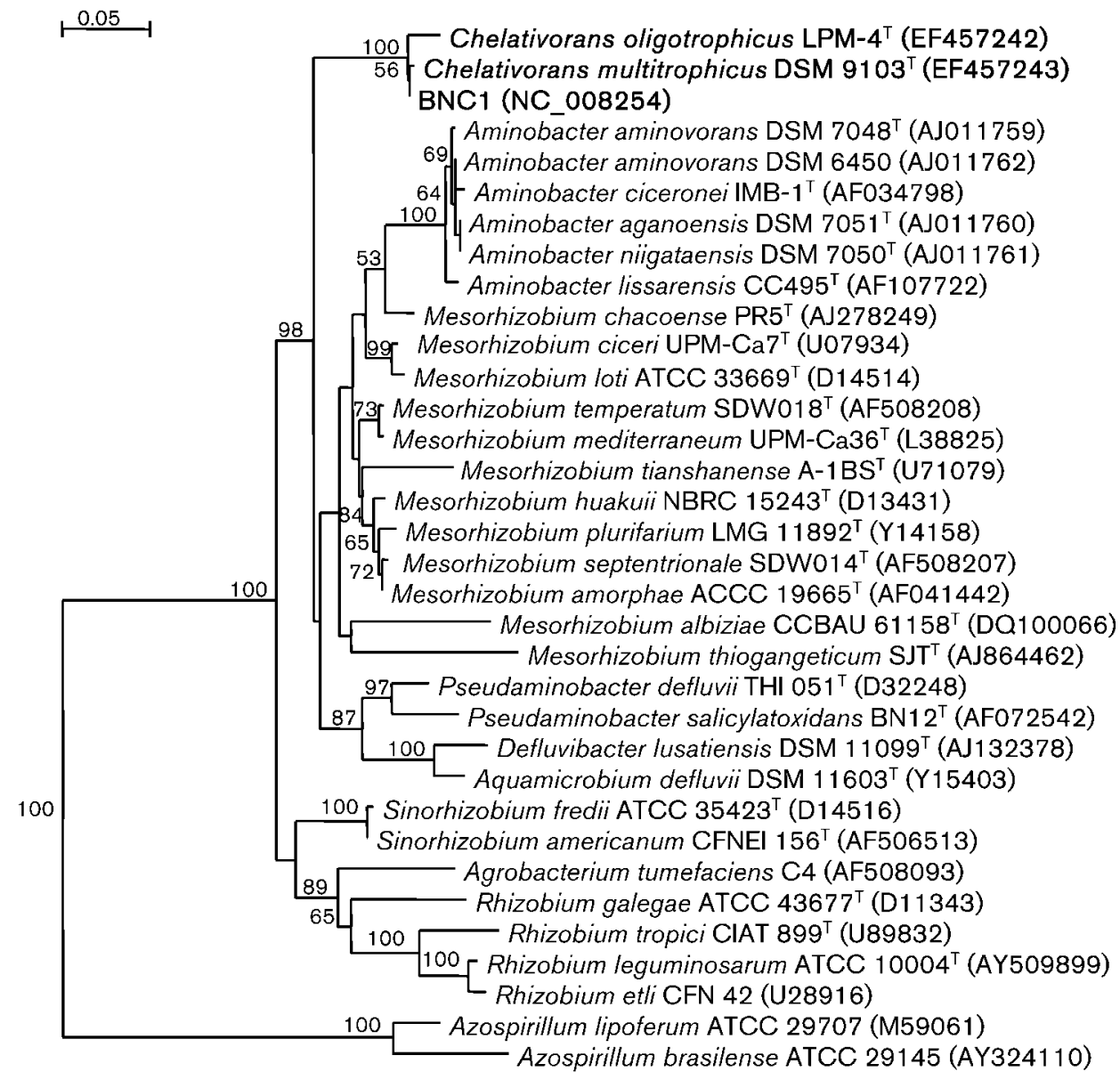

Fig. 2. Phylogenetic position of Chelativorans multitrophicus DSM $9103^{\top}$ and Chelativorans oligotrophicus $\mathrm{LPM}^{\top} 4^{\top}$ among related micro-organisms based on 16S rRNA gene sequences. All the sequences were aligned using the CLUSTAL W program. The similarity values were calculated with the Jukes-Cantor coefficient. The neighbour-joining method was used for construction of the phylogenetic tree and 100 subsamples were generated for bootstrap analysis using the TREECON program (1.3b). Escherichia coli 0157:H7 (AY513502) was used as an outgroup. Bar, 0.05 substitutions per base position.

Gram-negative, asporogenous, non-pleomorphic, rodshaped and often found as pairs of cells. Non-motile. Multiply by binary fission. Form small white colonies (0.1$0.3 \mathrm{~mm}$ in diameter) on EDTA/mineral salt agar incubated for 7 days at $30{ }^{\circ} \mathrm{C}$. Electron-dense inclusions found in EDTA-grown cells are thought to represent intracellular precipitates consisting of calcium and magnesium phosphates which are absent in fumarate-grown cells. PHB granules are absent. Oxidase- and catalase-positive. Do not reduce nitrate to nitrite. Do not fix atmospheric nitrogen. Mesophilic and neutrophilic; optimal $\mathrm{pH}$ and temperature for growth are $6.5-7.5$ and $25-35{ }^{\circ} \mathrm{C}$, respectively. Strictly aerobic with respiratory metabolism. Facultative or obligate utilizers of EDTA as the carbon, nitrogen and energy source. Do not utilize methanol and methylated amines as the carbon, nitrogen and energy source. Incapable of autotrophic or methylotrophic growth. Biotin is required as a growth factor. Oxidize EDTA by monooxygenase consuming flavin mononucleotide (FMN) $\mathrm{H}_{2}$ delivered by a $\mathrm{NADH}_{2}: \mathrm{FMN}$ oxidoreductase. The major cellular fatty acids are summed feature 7 (consisting of $\mathrm{C}_{18: 1} \omega 7 c$, $\mathrm{C}_{18: 1} \omega 9 t$ and/or $\left.\mathrm{C}_{18: 1} \omega 12 t\right)$ and $\mathrm{C}_{19: 0}$ cyclo $\omega 8 c$. Hydroxy fatty acids such as $\mathrm{C}_{12: 0} 3-\mathrm{OH}, \mathrm{C}_{13: 0} 3-\mathrm{OH}$ and $\mathrm{C}_{15: 0}$ iso 3-OH are absent. The major ubiquinone is Q-10. Predominant polar lipids are PC, PG, PE, PDE, PME and DP. Mesorhizobium-specific ornithine lipid is absent. The major polyamine is sym-homospermidine and small amounts of spermidine and putrescine are detected. The DNA G $+\mathrm{C}$ content is $60-64 \mathrm{~mol} \%\left(T_{\mathrm{m}}\right)$. The genus is a member of the class Alphaproteobacteria. The type species is Chelativorans multitrophicus.

\section{Description of Chelativorans multitrophicus sp. nov.}

Chelativorans multitrophicus (mu.lti.tro'phi.cus. L. adj. multus many; Gr. adj. trophikos nursing, tending; N.L. masc. adj. multitrophicus utilizing many growth substrates). 
Table 1. Main characteristics that differentiate the genera Chelativorans, Aminobacter, Mesorhizobium, Pseudaminobacter, Aquamicrobium and Defluvibacter

Taxa: 1, Chelativorans gen. nov. (data from this study); 2, Aminobacter (Urakami et al., 1992; Kämpfer et al., 2002); 3, Mesorhizobium (Jarvis et al., 1982, 1997; Tighe et al., 2000); 4, Pseudaminobacter (Kämpfer et al., 1999); 5, Aquamicrobium (Bambauer et al., 1998); 6, Defluvibacter (Fritsche et al., 1999). +, Positive; -, negative; +/- variable; ND, not determined or data are not available for the taxon.

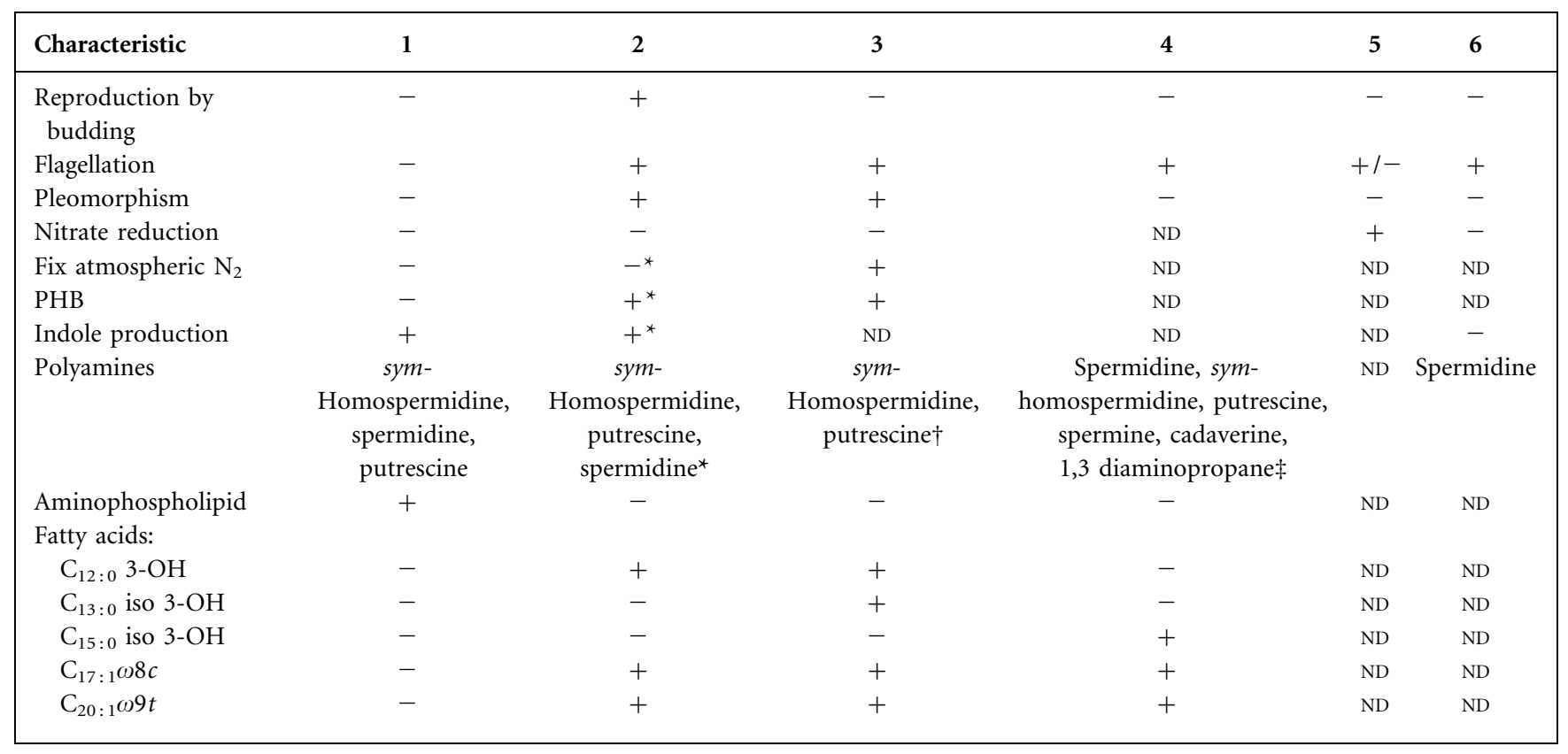

${ }^{\star}$ Data from this study.

$\dagger$ Data from Hamana et al., 1990.

\$Data are for Pseudaminobacter salicylatoxidans $\mathrm{BN} 12^{\mathrm{T}}$ (Kämpfer et al., 1999).

Exhibits the following properties in addition to those given in the genus description. Facultative EDTA-utilizing rods of $0.5-1.0 \times 0.7-2.0 \mu \mathrm{m}$. Grows on glucose, lactate, glutamate, fumarate, succinate, acetate, nitrilotriacetate, iminodiacetate, $N, N^{\prime}$-ethylenediaminediacetate, and ethylenediaminedisuccinate as the sole carbon and energy sources. No growth on diethylenetriaminepentaacetate or hydroxyethylethylenediaminetriacetate. The generation time with EDTA as the source of carbon, nitrogen and energy at $\mathrm{pH} 7.0$ and $30{ }^{\circ} \mathrm{C}$ is $14 \mathrm{~h}$. Good, but slow growth on complex media at low concentrations of organic compounds, such as Plate Count Broth at one third of the normal strength. No growth in the presence of $3 \%$ $(\mathrm{w} / \mathrm{v}) \mathrm{NaCl}$. Able to degrade uncomplexed EDTA and $\mathrm{Ca}^{2+}{ }_{-}, \mathrm{Ba}^{2+}-, \mathrm{Mg}^{2+}{ }_{-}, \mathrm{Mn}^{2+}, \mathrm{Pb}^{2+}{ }_{-}, \mathrm{Cu}^{2+}{ }_{-}$or $\mathrm{Zn}^{2+}$ EDTA complexes, but not $\mathrm{Fe}^{3+}$-EDTA complex. Resistant to oxacillin, ampicillin and lincomycin, but sensitive to gentamicin, streptomycin, novobiocin, nalidixic acid and neomycin. Shows $\alpha$-ketoglutarate dehydrogenase activity.

The type strain, DSM $9103^{\mathrm{T}}\left(=\mathrm{VKM} \quad \mathrm{B}-2394^{\mathrm{T}}\right)$, was isolated from a mixture of soil extracts and activated sludge samples taken from various industrial wastewater treatment plants (Switzerland). The DNA G $+\mathrm{C}$ content of the type strain is $63.1 \mathrm{~mol} \%\left(T_{\mathrm{m}}\right)$.

\section{Description of Chelativorans oligotrophicus sp. nov.}

Chelativorans oligotrophicus (o.li.go.tro'phicus. Gr. adj. oligos little; Gr. adj. trophikos nursing, tending; N.L. masc. adj. oligotrophicus utilizing only a few growth substrates).

Exhibits the following properties in addition to those given in the genus description. Obligate EDTA-utilizing rods of $0.5-1.0 \times 0.7-2.0 \mu \mathrm{m}$. The generation time of the strain grown with EDTA as the source of carbon, nitrogen and energy at $\mathrm{pH} 7.0$ and $32-34{ }^{\circ} \mathrm{C}$ is $7 \mathrm{~h}$. Able to degrade uncomplexed EDTA and $\mathrm{Mn}^{2+}, \mathrm{Ca}^{2+}, \mathrm{Mg}^{2+}$ - and $\mathrm{Ba}^{2+}$-EDTA and slowly degrade $\mathrm{Zn}^{2+}$-EDTA, but not $\mathrm{Pb}^{2+}-, \mathrm{Cu}^{2+}-$ or $\mathrm{Fe}^{3+}$-EDTA. Does not grow on peptone/ yeast extract medium, nutrient broth, nutrient agar or in medium containing carbohydrates (D-glucose, D-fructose) or amino acids, or ethanol or methanol or organic acids (acetate, fumarate, succinate and citrate). Resistant to oxacillin, ampicillin, novobiocin, lincomycin, nalidixic acid, neomycin, but sensitive to gentamicin and streptomycin. Has multiple enzymic lesions in the central carbon metabolism. The tricarboxylic acid cycle is deficient in $\alpha$-ketoglutarate dehydrogenase activity. The activities of 6-phosphofructokinase (ATP/PPi) are also absent. 
The type strain, $\mathrm{LPM}-4^{\mathrm{T}}\left(=\mathrm{VKM} \mathrm{B}-2395^{\mathrm{T}}=\mathrm{DSM} 19276^{\mathrm{T}}\right)$, was isolated from municipal sewage sludge samples taken near Pushchino, Moscow region, Russia. The DNA G $+\mathrm{C}$ content of the type strain is $60.8 \mathrm{~mol} \%\left(T_{\mathrm{m}}\right)$.

\section{Acknowledgements}

The authors wish to thank Drs T. I. Chistyakova, N. E. Suzina, I. G. Minkevich, E. Lang, C. Spröer and Ms W. Palme for their help. Special thanks are due to Professor P. Kämpfer, Dr J. Euzéby and anonymous reviewers for their valuable comments and advice. This work was supported by grants RFBR 06-04-49580a and Ministry of Education and Science RF RNP 2.1.1. 605.

\section{References}

Altenburger, P., Kämpfer, P., Makristathis, A., Lubitz, W. \& Busse, H.-J. (1996). Classification of bacteria isolated from a medieval wall painting. J Biotechnol 47, 39-52.

Andreev, L. V. \& Galchenko, V. F. (1983). Phospholipid composition and differentiation of methanotrophic bacteria. J Liq Chromatogr 6, 2699-2707.

Bambauer, A., Rainey, F. A., Stackebrandt, E. \& Winter, J. (1998). Characterization of Aquamicrobium defluvii gen. nov. sp. nov., a thiophene-2-carboxylate-metabolizing bacterium from activated sludge. Arch Microbiol 169, 293-302.

Bohuslavek, J., Payne, J. W., Liu, Y., Bolton, H. \& Xun, L. (2001). Cloning, sequencing, and characterization of a gene cluster involved in EDTA degradation from the bacterium BNC1. Appl Environ Microbiol 67, 688-695.

Bucheli-Witschel, M. \& Egli, T. (2001). Environmental fate and microbial degradation of aminopolycarboxylic acids. FEMS Microbiol Rev 25, 69-106.

Chistyakova, T. I., Dedyukhina, E. G., Satroutdinov, A. D., Kaparullina, E. N., Gavrish, E. Yu. \& Eroshin, V. K. (2005). EDTAdependent bacterial strain. Process Biochem 40, 601-605.

Choma, A. \& Komaniecka, I. (2002). Analysis of phospholipids and ornithine-containing lipids from Mesorhizobium spp. Syst Appl Microbiol 25, 326-331.

Collins, M. D. (1985). Analysis of isoprenoid quinones. Methods Microbiol 18, 329-366.

Doronina, N. V., Trotsenko, Y. A. \& Tourova, T. P. (2000). Methylarcula marina gen. nov., sp. nov. and Methylarcula terricola sp. nov.: novel aerobic, moderately halophilic, facultatively methylotrophic bacteria from coastal saline environments. Int J Syst Evol Microbiol 50, 1849-1850.

Doronina, N. V., Darmaeva, T. D. \& Trotsenko, Y. A. (2003). Methylophaga alcalica sp. nov., a novel alkaliphilic and moderately halophilic, obligately methylotrophic bacterium from an East Mongolian saline soda lake. Int J Syst Evol Microbiol 53, 223-229.

Doronina, N. V., Kaparullina, E. N., Vainshtein, M. B. \& Trotsenko, Y. A. (2006). Metabolic peculiarities of an obligate degrader of ethylenediaminetetraacetate. Microbiology (English translation of Mikrobiologiia) 75, 358-361.

Egli, T., Weilenmann, H. U., El-Banna, T. \& Auling, G. (1988). Gramnegative, aerobic, nitrilo-triacetate-utilizing bacteria from wastewater and soil. Syst Appl Microbiol 10, 297-305.

Fedorov, D. N., Ivanova, E. G., Doronina, N. V. \& Trotsenko, Yu. A. (2008). A new system of degenerate oligonucleotide primers for detection and amplification of nifHD genes. Microbiology (English translation of Mikrobiologiia) 77, 247-249.
Fritsche, K., Auling, G., Andreesen, J. R. \& Lechner, U. (1999). Defluvibacter lusatiae gen. nov., sp. nov., a new chlorophenoldegrading member of the alpha-2 subgroup of Proteobacteria. Syst Appl Microbiol 22, 197-204.

Gerhardt, P., Murray, R. G. E., Wood, W. A. \& Krieg, N. R. (1994). Methods of General and Molecular Bacteriology. Washington, DC; American Society for Microbiology.

Hamana, K., Minamisawa, K. \& Matsuzaki, S. (1990). Polyamines in Rhizobium, Bradyrhizobium, Azorhizobium and Agrobacterium. FEMS Microbiol Lett 71, 71-76.

Jarvis, B. D. W., Pankhurst, C. E. \& Patel, J. J. (1982). Rhizobium loti, a new species of legume root nodule bacteria. Int J Syst Bacteriol 32, 378-380.

Jarvis, B. D. W., Van Berkum, P., Chen, W. X., Nour, S. M., Fernandez, M. P., Cleyet-Marel, J. C. \& Gillis, M. (1997). Transfer of Rhizobium loti, Rhizobium huakuii, Rhizobium ciceri, Rhizobium mediterraneum, and Rhizobium tianshanense to Mesorhizobium gen. nov. Int J Syst Bacteriol 47, 895-898.

Jukes, T. N. \& Cantor, C. R. (1969). Evolution of protein molecules. In Mammalian Protein Metabolism, vol. 3, pp. 21-132. Edited by H. N. Munro. New York: Academic Press.

Kämpfer, P., Müller, C., Mau, M., Neef, A., Auling, G., Busse, H.-J., Osborn, A. M. \& Stolz, A. (1999). Description of Pseudaminobacter gen. nov. with two species, Pseudaminobacter salicylatoxidans sp. nov and Pseudaminobacter defluvii sp. nov. Int J Syst Bacteriol 49, 887897.

Kämpfer, P., Neef, A., Salkinoja-Salonen, M. S. \& Busse, H.-J. (2002). Chelatobacter heintzii is a later subjective synonym of Aminobacter aminovorans. Int J Syst Evol Microbiol 52, 835-839.

Korotkova, N. A., Ashin, V. V., Doronina, N. V. \& Trotsenko, Yu. A. (1997). A new method for quantitative determination of poly-3hydroxybutyrate and 3-hydroxybutyrate-3-hydroxyvalerate copolymer in microbial biomass by reversed-phase high-performance liquid chromatography. Appl Biochem Microbiol 33, 339-343 (English translation of Prikl Biokhim Microbiol).

Lane, D. J. (1991). 16S/23S rRNA sequencing. In Nucleic acid techniques in bacterial systematics, pp. 115-175. Edited by E. Stackebrandt \& M. Goodfellow. Chichester: John Wiley and Sons.

Lauff, J. J., Steele, D. B., Coogan, L. A. \& Breitfeller, J. M. (1990). Degradation of the ferric chelate of EDTA by a pure culture of an Agrobacterium sp. Appl Environ Microbiol 56, 3346-3353.

Marmur, J. A. (1961). A procedure for the isolation of deoxyribonucleic acid from microorganisms. J Mol Biol 3, 208-214.

Nörtemann, B. (1992). Total degradation of EDTA by mixed cultures and a bacterial isolate. Appl Environ Microbiol 58, 671-676.

Nörtemann, B. (1999). Biodegradation of EDTA. Appl Microbiol Biotechnol 51, 751-759.

Nörtemann, B., Cordes, C., Lang, E. \& Busse, H.-J. (2004). Classification of EDTA-degrading bacteria. In Annual Meeting of the German Society of Microbiology VAAM, Poster no. PA011, Biospektrum, special edition, 74 .

Nörtemann, B. (2005). Biodegradation of chelating agents: EDTA, DTPA, PDTA, NTA, and EDDS. In Biogeochemistry of Chelating Agents (ACS Symposium Series vol. 910), pp. 150-170. Edited by B. Nowak \& J. M. VanBriesen.

Owen, R. J. \& Lapage, S. P. (1976). The thermal denaturation of partly purified bacterial deoxyribonucleic acid and its taxonomic applications. J Appl Bacteriol 41, 335-340.

Palumbo, A. V., Lee, S. Y. \& Boerman, P. (1994). The effect of media composition on EDTA degradation by Agrobacterium sp. Appl Biochem Biotechnol 45-46, 811-822. 
Pfennig, N., Widdel, F. \& Trüper, H. G. (1981). The dissimilatory sulfate-reducing bacteria. In The Prokaryotes, vol. 1, pp. 926-940. Edited by M. P. Starr, H. Stolp, H. G. Trüper, H. Balows \& H. G. Schlegel. Berlin: Springer Verlag.

Potthoff-Karl, B., Greindl, T. \& Oftring, A. (1996). Synthese abbaubarer Komplexbildner und ihre Reinigungsformulierungen. SOEFW J 122, 392-397 (in German).

Sillanpaa, M. (1997). Environmental fate of EDTA and DTPA. Rev Environ Contam Toxicol 152, 85-111.

Skidmore, W. D. \& Entenman, C. (1962). Two dimensional thin-layer chromatography of rat liver phosphatides. J Lipid Res 3, 471-475.

Stackebrandt, E. \& Goebel, B. M. (1994). Taxonomic note: a place for DNA-DNA reassociation and $16 \mathrm{~S}$ rRNA sequence analysis in the present species definition in bacteriology. Int J Syst Bacteriol 44, 846849.

Tamura, K., Dudley, J., Nei, M. \& Kumar, S. (2007). MEGA4: molecular evolutionary genetics analysis (MEGA) software version 4.0. Mol Biol Evol 8, 1596-1599.

Tighe, S. W., de Lajudie, P., Dipietro, K., Lindstroem, K., Nick, G. \& Jarvis, B. D. W. (2000). Analysis of cellular fatty acid and phenotypic relationships of Agrobacterium, Bradyrhizobium, Mesorhizobium, Rhizobium and Sinorhizobium species using the Sherlock microbial identification system. Int J Syst Evol Microbiol 50, 787-801.

Tindall, B. J. (1990). Lipid composition of Halobacterium lacusprofundi. FEMS Microbiol Lett 66, 199-202.
Tkachenko, A. G., Shumkov, M. S. \& Akhova, A. V. (2006). Putrescine as a modulator of the level of RNA polymerase $\sigma^{\mathrm{s}}$ subunit in Escherichia coli under acid stress. Biochemistry 71, 185-193 (Moscow).

Urakami, T., Araki, H., Oyanagi, H., Suzuki, K.-I. \& Komagata, K. (1992). Transfer of Pseudomonas aminovorans (den Dooren de Jong 1926) to Aminobacter gen. nov. as Aminobacter aminovorans comb. nov. and description of Aminobacter aganoensis sp. nov. and Aminobacter niigataensis sp. nov. Int J Syst Bacteriol 42, 84-92.

Van de Peer, Y. \& De Wachter, R. (1994). TREECON for Windows: a software package for the construction and drawing of evolutionary trees for the Microsoft Windows environment. Comput Appl Biosci 10, 569-570.

Weilenmann, H.-U., Engeli, B., Bucheli-Witschel, M. \& Egli, T. (2004). Isolation and growth characteristics of an EDTA-degrading member of the $\alpha$-subclass of Proteobacteria. Biodegradation 15, 289-301.

Witschel, M., Nagel, S. \& Egli, T. (1997). Identification and characterization of the two-enzyme system catalyzing oxidation of EDTA in the EDTA-degrading bacterial strain DSM 9103. J Bacteriol 179, 6937-6943.

Young, J. M., Kuykendall, L. D., Martinez-Romero, E., Kerr, A. \& Sawada, H. (2001). A revision of Rhizobium Frank 1889, with an emended description of the genus, and the inclusion of all species of Agrobacterium Conn 1942 and Allorhizobium undicola de Lajudie et al. 1998 as new combinations: Rhizobium radiobacter, $R$. rhizogenes, R. rubi, R. undicola and R. vitis. Int J Syst Evol Microbiol 51, 89-103. 